\title{
Joining of Zirconium Diboride-Based Ceramic Composites to Metallic Systems for High-Temperature Applications
}

\author{
R. Asthana ${ }^{1}$ and M. Singh ${ }^{2}$ \\ ${ }^{1}$ Department of Engineering and Technology \\ University of Wisconsin-Stout \\ Menomonie, WI 54751 \\ ${ }^{2}$ Ohio Aerospace Institute, MS 106-5 \\ NASA Glenn Research Center \\ Cleveland, $\mathrm{OH} 44135$
}

\begin{abstract}
$\underline{\text { Abstract }}$
Three types of hot-pressed zirconium diboride ( $\mathrm{ZrB}_{2}$ )-based ultra-high-temperature ceramic composites (UHTCC), $\mathrm{ZrB}_{2}$-SiC (ZS), $\mathrm{ZrB}_{2}$-SiC-C (ZSC), and $\mathrm{ZrB}_{2}-\mathrm{SCS} 9-\mathrm{SiC}$ (ZSS), were joined to $\mathrm{Cu}-\mathrm{Clad}-\mathrm{Mo}$ using two $\mathrm{Ag}-\mathrm{Cu}$ brazes (Cusil-ABA and Ticusil, $\mathrm{T}_{\mathrm{L}} \sim 1073-1173^{\circ} \mathrm{K}$ ) and two Pd-base brazes (Palco and Palni, $\mathrm{T}_{\mathrm{L}} \sim 1493-1513^{\circ} \mathrm{K}$ ). Scanning Electron Microscopy (SEM) coupled with energy-dispersive spectroscopy (EDS) revealed greater chemical interaction in joints made using Pd-base brazes than in joints made using Ag-Cu based active brazes. The degree of densification achieved in hot pressed composites influenced the Knoop hardness of the UHTCC and the hardness distribution across the braze interlayer. The braze region in Pd-base system displayed higher hardness in joints made using fully-dense ZS composites than in joints made using partially-dense ZSS composites and the carbon-containing ZSC composites. Calculations indicate a small negative elastic strain energy and an increase in the UHTCC's fracture stress up to a critical

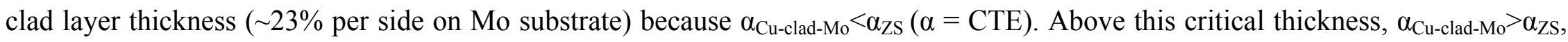
strain energy in the UHTCC is positive, and it increases with increasing clad layer thickness. Empirical projections show a reduction in the effective thermal resistance of the joints and highlight the potential benefits of joining the UHTCC to Cu-clad-Mo.
\end{abstract}


National Aeronautics and Space Administration

Joining of Zirconium Diboride-Based Ceramic Composites to Metallic Systems for High Temperature Applications

\author{
R. Asthana* and M. Singh** \\ * Department of Engineering \& Technology \\ University of Wisconsin-Stout \\ Menomonie, WI 54751 \\ **Ohio Aerospace Institute \\ NASA Glenn Research Center \\ Cleveland, OH 44135
}

National Aeronautics and Space Administration

\title{
Overview
}

- Introduction and Background

- Experimental Procedure

- Active Metal Brazing

- Characterization (SEM, EDS)

- Hardness behavior

- Results and Discussion

- Ag-Cu based brazes

- Pd based brazes

- Strain energy calculations

- Estimation of joint conductance

- Concluding Remarks

- Acknowledgment 
National Aeronautics and Space Administration

\section{Introduction and Background}

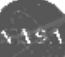

- $\mathrm{ZrB}_{2}$ has high melting point $(\sim 3493 \mathrm{~K})$, good oxidation resistance and low density $\left(6,090 \mathrm{~kg} \cdot \mathrm{m}^{-3}\right)$.

- $\mathrm{ZrB}_{2}$-based UHTCC have potential to operate at 2150$2770 \mathrm{~K}$ in applications such as nose cap and sharp leading edges of space vehicles.

-High-temperature strength, fracture toughness, oxidation resistance, and thermal shock resistance reported in the literature. However, scant work on joining of $\mathrm{ZrB}_{2}$-based UHTCC to metallic systems has been reported.

- Muolo et al, Proc. 9th International Symposium on Materials in a Space Environment, June 2003.

- Singh and Asthana, Mater. Sci. Eng. A, 460-461 153-162 (2007).

- Singh and Asthana, Int. J. Applied Ceramic Technology (in press, 2008).

\section{Objective}

- Utilize active metal brazing approach to join three $\mathrm{ZrB}_{2}$-based ultra high temperature ceramic composites (UHTCC) to Cu-clad-Mo using two Pd-base brazes $\left(T_{L} \sim 1492-1511 \mathrm{~K}\right)$ and two AgCuTi brazes $\left(T_{L} \sim 1073-\right.$ $1173 \mathrm{~K})$.

- Characterize the joint microstructure, composition, and microhardness distribution across the joint interface.

- Estimate the residual stress and effective thermal resistance in the joint. 
National Aeronautics and Space Administration

\section{Challenges in Joining of $\mathrm{ZrB}_{2}$-Based Ultra High Temperature Ceramic Composites}

-Wettability: flow and spreading characteristics.

Pd-base brazes:

- No wettability data for $\mathrm{Pd}$ on $\mathrm{ZrB}_{2}$.

- $\theta$ of $\mathrm{Co}\left(\sim 39^{\circ}\right)$ and $\mathrm{Ni}\left(\sim 2^{\circ}\right)$ at $1773 \mathrm{~K}$ indicates wetting.

- Pd-base brazes may also wet $\mathrm{ZrB}_{2}$.

\section{Ag-Cu brazes:}

- Cu wets $\mathrm{ZrB}_{2}\left(\theta \sim 80^{\circ}\right.$ at $\left.1413 \mathrm{~K}\right)$.

- Ag does not wet $\mathrm{ZrB}_{2}\left(\theta \sim 114^{\circ}\right.$ at $\left.1373 \mathrm{~K}\right)$.

- $\mathrm{Ti}, \mathrm{Zr}$, or $\mathrm{Hf}$ in $\mathrm{Ag}$ improve the wetting $\left(\theta \sim 20-80^{\circ}\right)$.

- Cusil-ABA (1.75\% Ti) and Ticusil (4.5\% Ti) shall wet ZrB.

\section{Challenges in Joining of $\mathrm{ZrB}_{2}$-Based Ultra High Temperature Composites}

- Thermoelastic incompatibility: thermal expansion mismatch.

- CTE of $\mathrm{ZrB}_{2}$-based UHTCC $\sim 7.5 \times 10^{-6} / \mathrm{K}$.

- CTE of Cu-clad-Mo $\sim 5.6-11.6 \times 10^{-6} / \mathrm{K}$ for 5 to $40 \%$ clad thickness.

- Thermal strain, $\Delta \alpha \Delta T$, can be decreased by controlling the clad layer thickness.

- Copper as a cladding on Mo shall serve as a stress-absorbing layer. 
National Aeronautics and Space Administration

\section{Experimental Procedure}

- Materials -

- Braze alloys: Palni, Palco, Cusil-ABA and Ticusil Morgan Advanced Ceramics, Hayward, CA.

- Composites: $\mathrm{ZrB}_{2}-\mathrm{SiC}_{\mathrm{p}}$ (ZS), $\mathrm{ZrB}_{2}-\mathrm{SCS} \mathrm{A}-\mathrm{SiC}_{\mathrm{p}}(\mathrm{ZSS}), \mathrm{ZrB}_{2^{-}}$ $\mathrm{SiC}_{\mathrm{p}}-\mathrm{C}_{\mathrm{p}}$ (ZSC)

Materials and Machines, Inc, Tucson, $A Z$

(Uni-axially hot-pressed in a graphite die. ZSS made by filament winding, slurry deposition, and hot-pressing)

- Cu-clad-Mo plates (Cu-Mo-Cu ratio: 13\%-74\%-13\%)

H.C. Starck, Inc., Newton, MA.

(Manufactured by rolling a Mo core sandwiched between two Cu layers)

\section{Composition and Properties of Brazes and Substrate Materials}

\begin{tabular}{|c|c|c|c|c|c|c|c|c|c|}
\hline $\begin{array}{c}\text { Braze Composition, (wt } \\
\%)\end{array}$ & $\begin{array}{l}\text { Density } \\
\mathrm{Kg} \cdot \mathrm{m}^{-3}\end{array}$ & $\begin{array}{l}\mathrm{T}_{\mathrm{L}}, \\
{ }^{\circ} \mathrm{K}\end{array}$ & $\overline{\mathrm{T}_{\mathrm{S}},{ }^{\circ} \mathrm{K}}$ & $\begin{array}{c}\mathrm{E}, \\
\mathrm{GPa}\end{array}$ & $\begin{array}{l}\text { YS, } \\
\text { MPa }\end{array}$ & $\begin{array}{l}\text { UTS, } \\
\text { MPa }\end{array}$ & $\begin{array}{c}\text { CTE, } \\
\times 10^{-6} \mathbf{K}^{-1}\end{array}$ & \% El. & $\begin{array}{c}\mathrm{K}, \\
\mathrm{W} / \mathrm{m} \cdot \mathrm{K}\end{array}$ \\
\hline $\begin{array}{c}\text { Cusil-ABA } \\
\text { (63Ag-35.3Cu-1.75Ti) }\end{array}$ & 18,500 & 1088 & 1053 & 83 & 271 & 346 & 18.5 & 42 & 180 \\
\hline $\begin{array}{c}\text { Ticusil } \\
\text { (68.8Ag-26.7Cu-4.5Ti) }\end{array}$ & 18,500 & 1173 & 1053 & 85 & 292 & 339 & 18.5 & 28 & 219 \\
\hline $\begin{array}{c}\text { Palco }{ }^{\oplus} \\
(65 \mathrm{Pd}-35 \mathrm{Co})\end{array}$ & - & 1492 & 1492 & -- & 341 & 661 & -- & 43 & 35 \\
\hline $\begin{array}{c}\text { Palni } \\
\text { (60Pd-40Ni) }\end{array}$ & 15,000 & 1511 & 1511 & -- & 772 & 978 & 15 & 23 & 42 \\
\hline
\end{tabular}

E: Young's modulus, YS: yield strength, UTS: tensile strength, CTE: coeff. of thermal expansion, \%El: percent elongation, $K$ : thermal conductivity.

\begin{tabular}{||c|c||}
\hline \hline Composite & Composition \\
\hline $\mathrm{ZrB}_{2}-\mathrm{SCS} 9 \mathrm{~A}-\mathrm{SiC}(\mathrm{ZSS})$ & $\mathrm{ZrB}_{2}+20 \mathrm{v} / \mathrm{o} \mathrm{SiC}$ particles $+35 \mathrm{v} / \mathrm{o} \mathrm{SCS} 9 \mathrm{~A}$ SiC fiber \\
\hline $\mathrm{ZrB}_{2}-\mathrm{SiC}-\mathrm{C}(\mathrm{ZSC})$ & $\mathrm{ZrB}_{2}+14 \mathrm{v} / \mathrm{o} \mathrm{SiC}$ particles $+30 \mathrm{v} / \mathrm{o}$ carbon \\
\hline $\mathrm{ZrB}_{2}-\mathrm{SiC}(\mathrm{ZS})$ & $\mathrm{ZrB}_{2}+20 \mathrm{v} / \mathrm{o} \mathrm{SiC}$ particles \\
\hline \hline
\end{tabular}

SCS-9A is a small ( $78 \mu \mathrm{m})$ diameter SiC fiber from Textron Specialty Materials, Lowell, MA. 
National Aeronautics and Space Administration

\section{Experimental Procedure}

- Substrates and braze foils cut into $2.54 \mathrm{~cm} \times 1.25 \mathrm{~cm} \times 0.25$ $\mathrm{cm}$ panels and ultrasonically cleaned.

- Two braze foils sandwiched between substrates and heated under vacuum $\left(\sim 10^{-6}\right.$ torr $)$ to $15-20{ }^{\circ} \mathrm{C}$ above braze $\mathrm{T}_{\mathrm{L}}$. After 5 min. soak, slowly cooled to room temperature.

- Brazed joints mounted in epoxy, ground, polished, and examined using optical microscopy and Scanning Electron Microscopy (JEOL JSM-740A) coupled with EDS.

- Microhardness (Knoop indenter) on Struers Duramin-A300 machine (200 g load, $10 \mathrm{~s}$ ). Four-to-six scans across each joint.

National Aeronautics and Space Administration

Microstructure of UHTC Composites
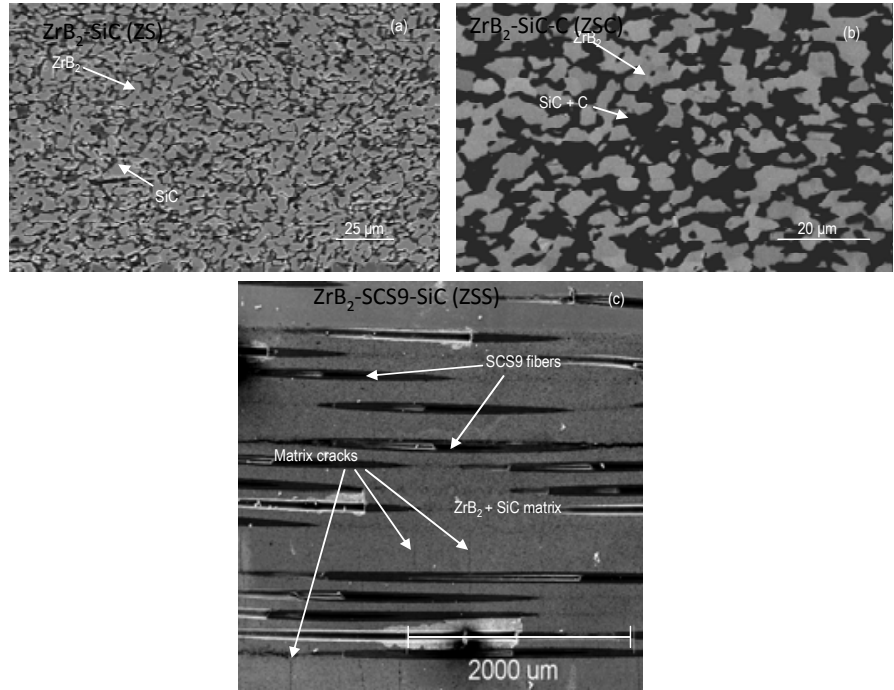

- Equi-axed $\mathrm{ZrB}_{2}$ particles ( 6-12 $\mu \mathrm{m}$ dia), tabular/plate-like SiC particles ( 3-11 $\left.\mu \mathrm{m} \times 1.5-3 \mu \mathrm{m}\right)$. - Transverse micro-cracks in ZSS due to CTE mismatch between $\mathrm{ZrB}_{2}$ and SCS9A fiber. 
National Aeronautics and Space Administration

UHTC Composites-Metal Joints Using Ag-Cu-Ti Active Braze Alloys

National Aeronautics and Space Administration

Microstructure of ZS/Cusil-ABA/Cu-clad-Mo joint
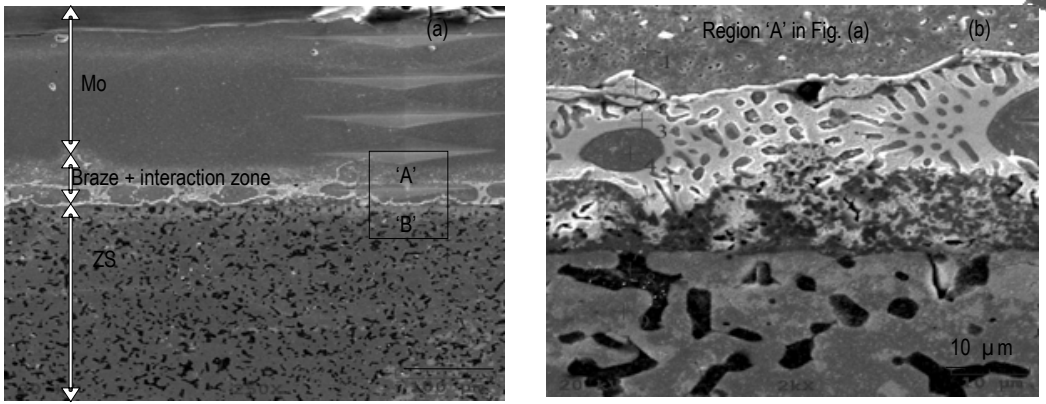

- Sound joint devoid of imperfections.

- Ag-Cu and Si-rich phases decorate the ZS/Cusil-ABA interface

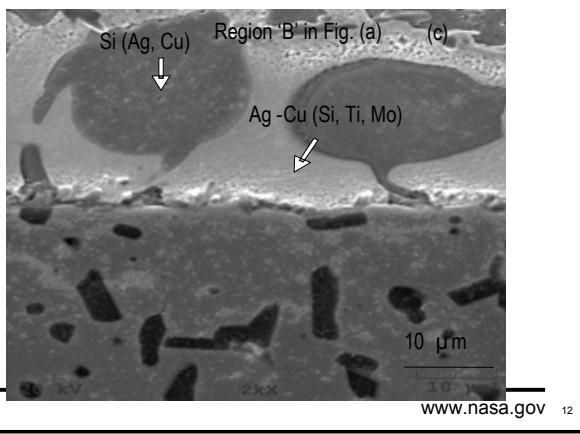


National Aeronautics and Space Administration

Microstructure of ZSC/Cusil-ABA/Cu-clad-Mo joint

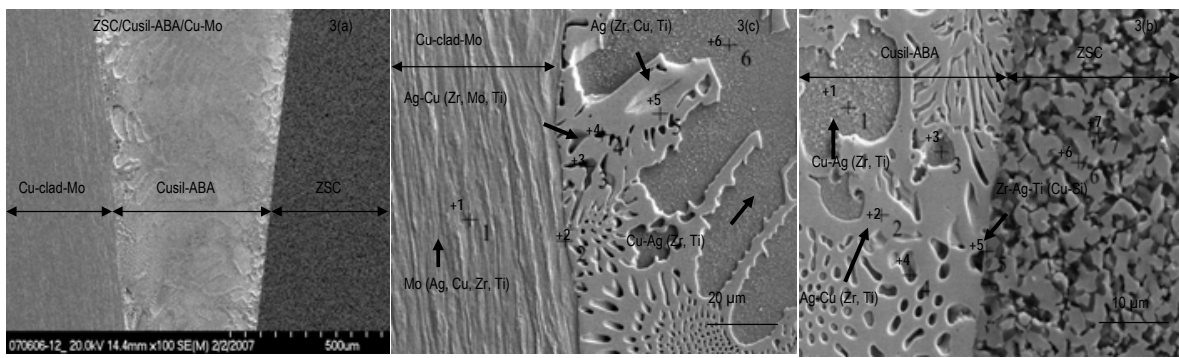

- Metal and composite substrates are covered with a Ag-rich phase.

- Relatively large ( 19at\%) amounts of Ag and $\mathrm{Ti}$ at the braze/ZSC

Interface.

-Small amounts of $\mathrm{Zr}$ and Mo in braze ( 4-5at\%).
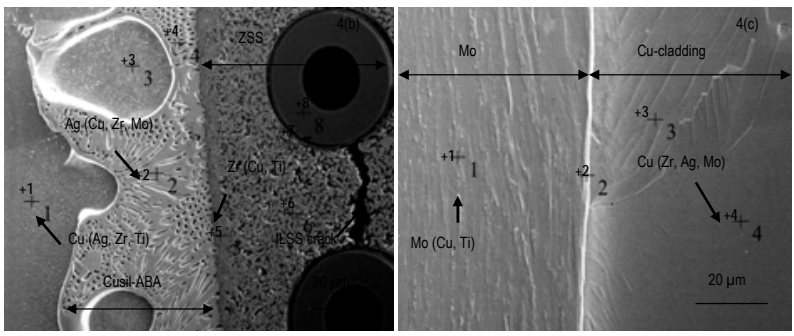

-Some longitudinal cracking in composite near joint.

- Minute (2-3 atom\%) dissolution of Zr in braze.

- Two-phase eutectic structure in braze (Ag- and $\mathrm{Cu}$-rich phases).

-Ag-rich phase deposited onto ZSS. 
National Aeronautics and Space Administration

Microstructure of ZS/Ticusil/Cu-clad-Mo joint
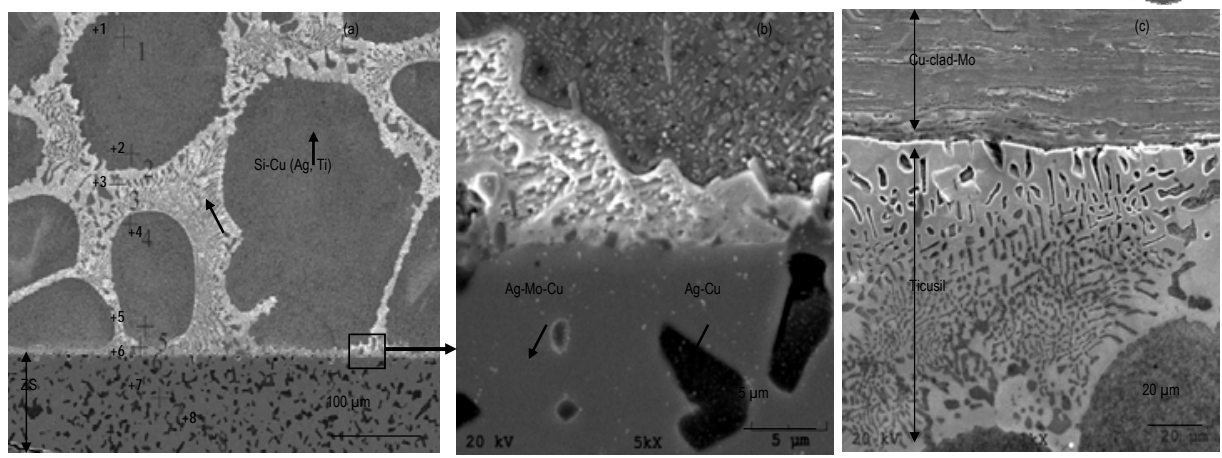

-Sound joint. Ti segregation at interface.

- Extensive Si dissolution in braze.

National Aeronautics and Space Administration

Microstructure of ZSC/Ticusil/Cu-clad-Mo joint
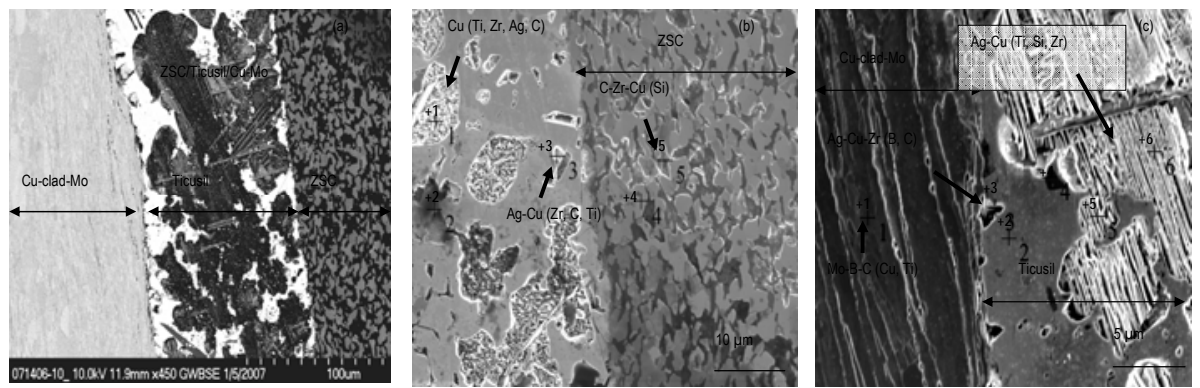

- $\mathrm{Zr}$ dissolution in braze (4-6 at\%).

- Cu diffusion in ZSC (4-10 at\%).

- $C$ and $B$ dissolution in braze (4-6 at\%). 
National Aeronautics and Space Administration

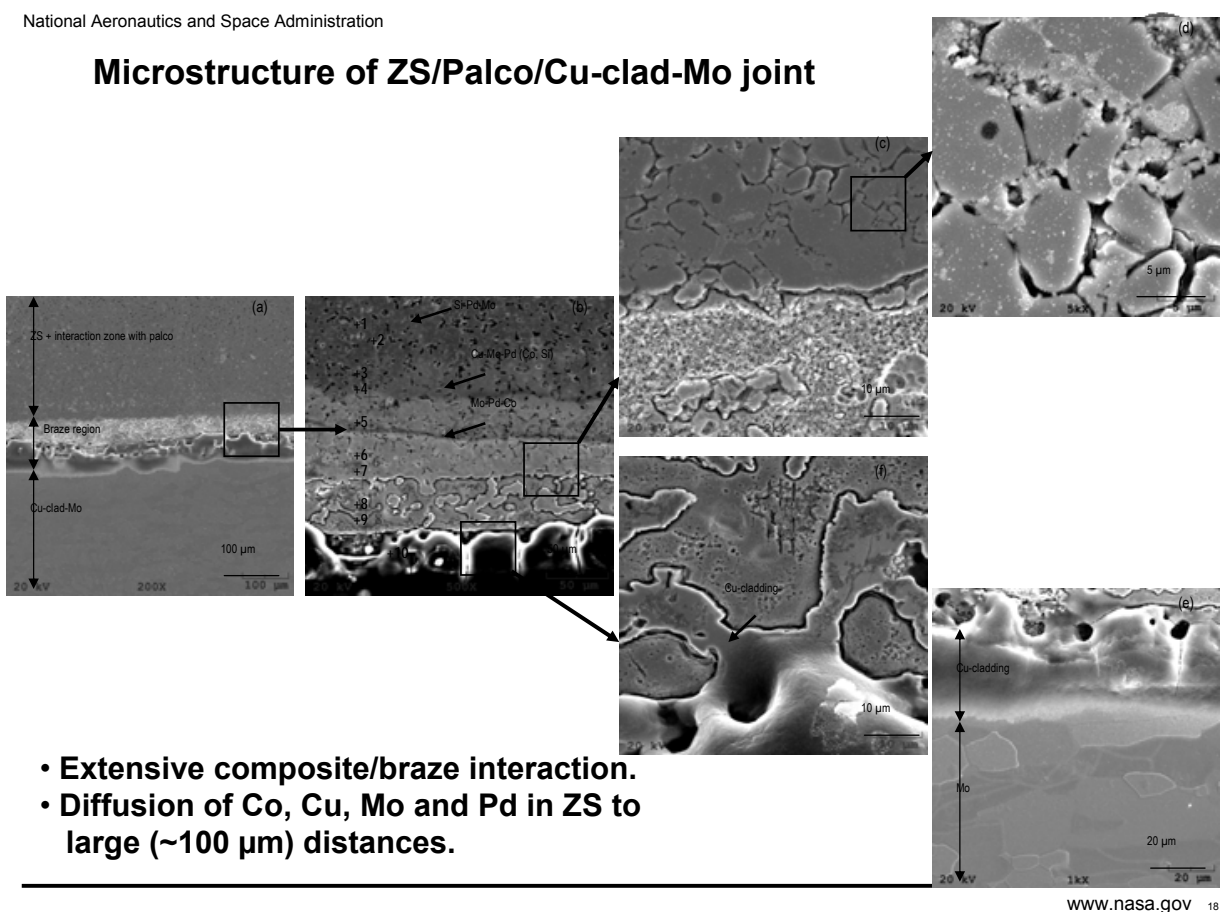


National Aeronautics and Space Administration Microstructure of ZSC/Palco/Cu-clad-Mo joint

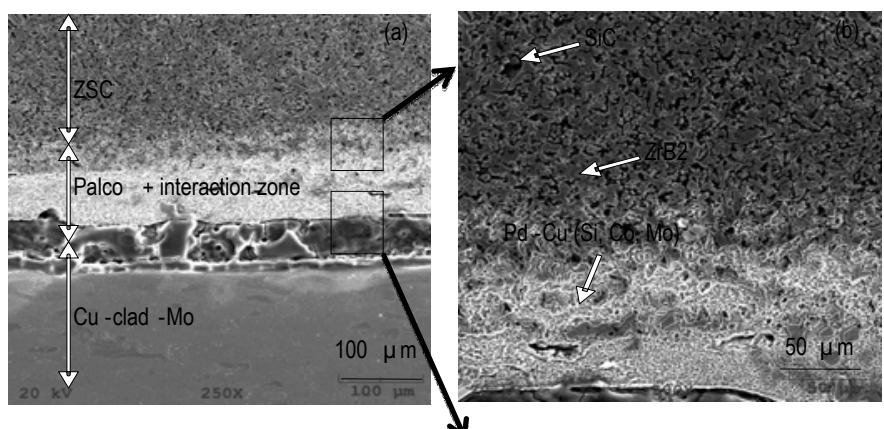

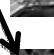

- Strong interaction.

- Co, Cu, Mo, Pd and Si in ZSC

- Large amounts of Pd and Si in clad layer which had melted.

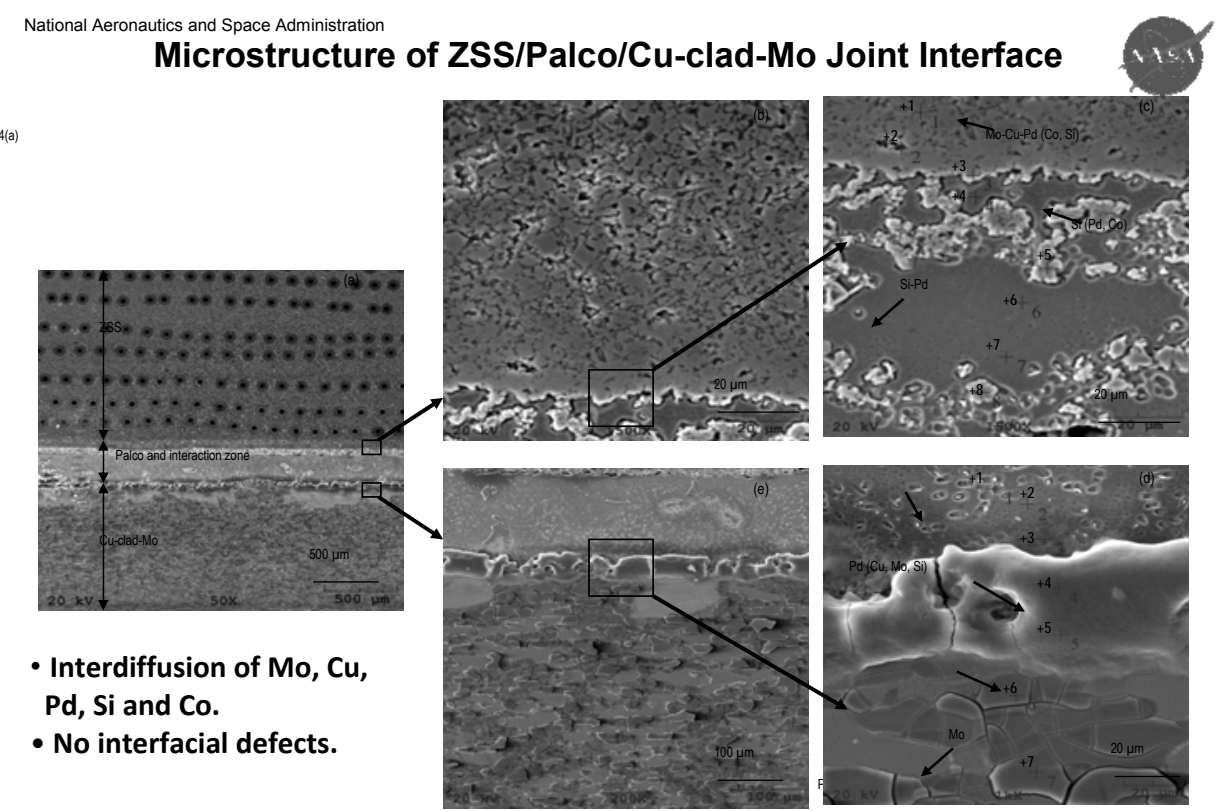




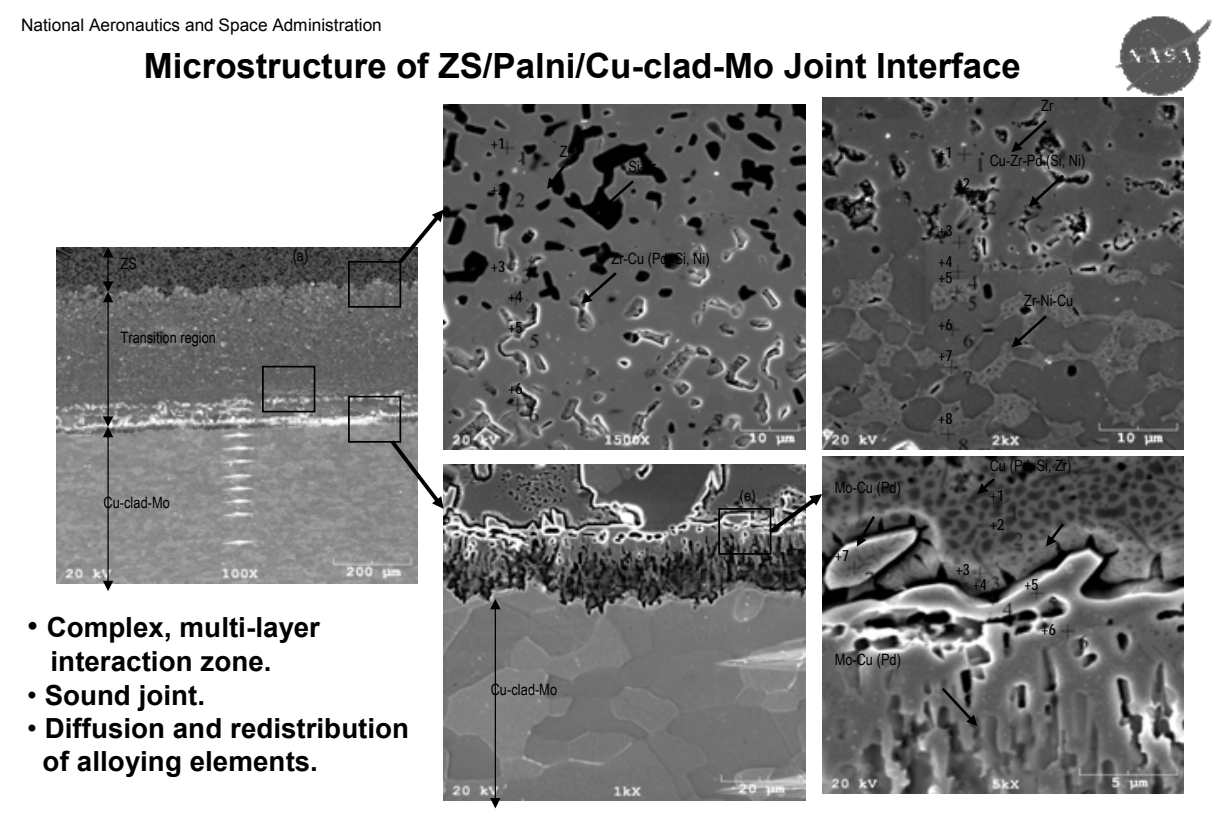

www.nasa.gov

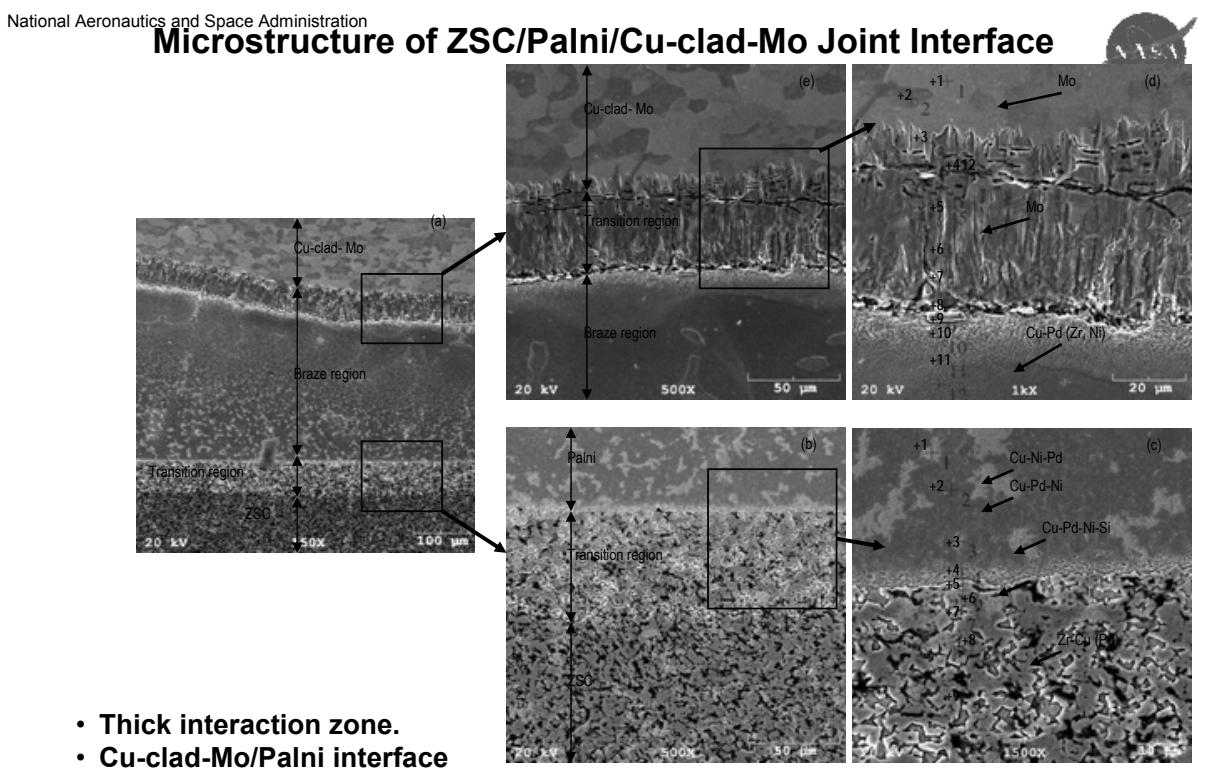

Cu-clad-Mo/Palni interface cracked. 
National Aeronautics and Space Administration Microstructure of ZSS/Palni/Cu-clad-Mo Joint Interface
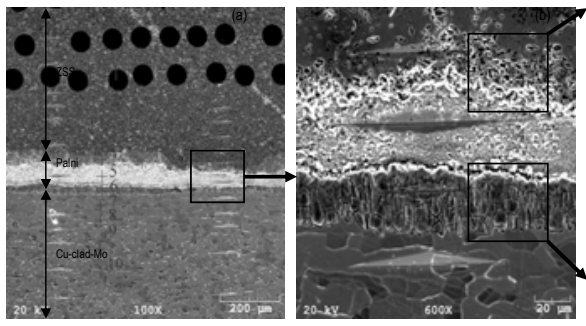

- Diffusion of Pd and $\mathrm{Cu}$ in ZSS.

- Interaction zone contains $\mathrm{Zr}, \mathrm{Ni}$, and small amounts of $\mathrm{Si}, \mathrm{Cu}$ and $\mathrm{Pd}$.
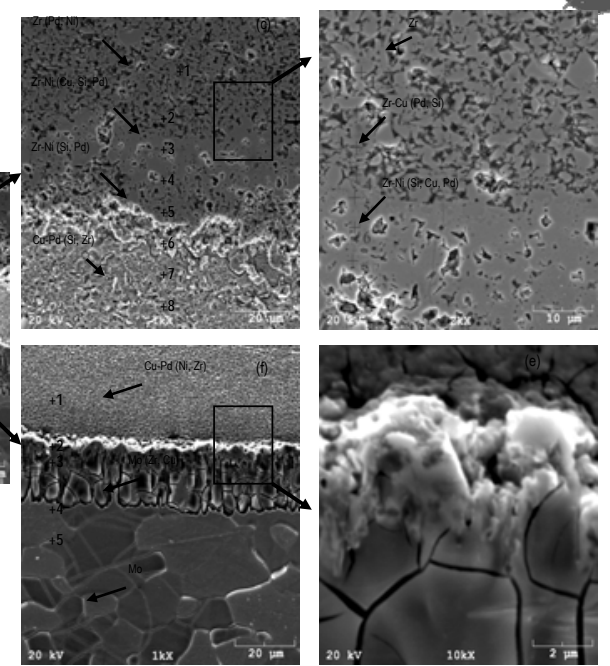

www.nasa.gov

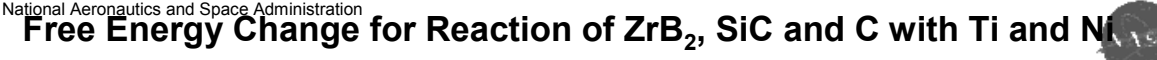
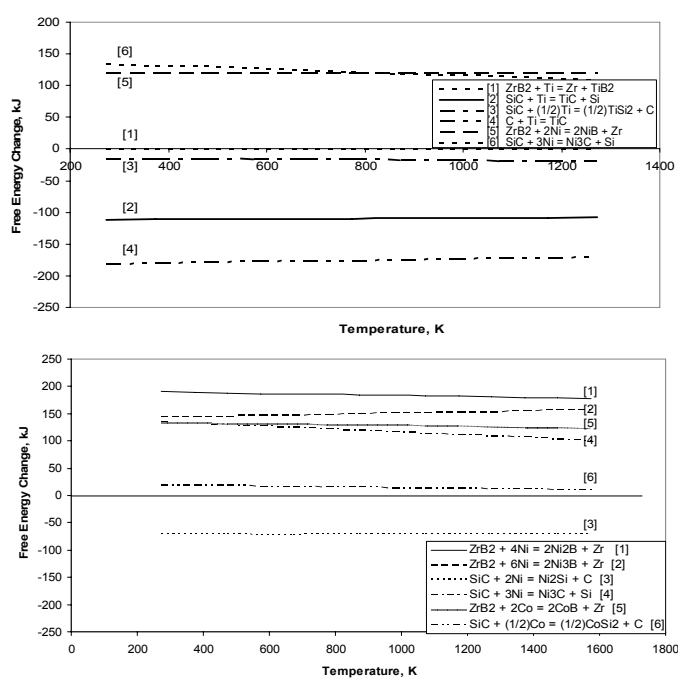

- TiC, $\mathrm{Ni}_{2} \mathrm{Si}$ and $\mathrm{TiSi}_{2}$ could form from the reaction of SiC with $\mathrm{Ti}$ and $\mathrm{Ni}$.

- $\mathrm{Pd}_{3} \mathrm{Zr}, \mathrm{Pd}_{2} \mathrm{Zr}, \mathrm{PdZr}$, and $\mathrm{PdZr}_{2}$, and $\mathrm{CoZr}, \mathrm{Co}_{2} \mathrm{Zr}$, and $\mathrm{CoZr}_{2}$ could also form (phase diagram). 
National Aeronautics and Space Administration

Knoop Hardness (HK) (Braze: Ag-Cu-Ti)
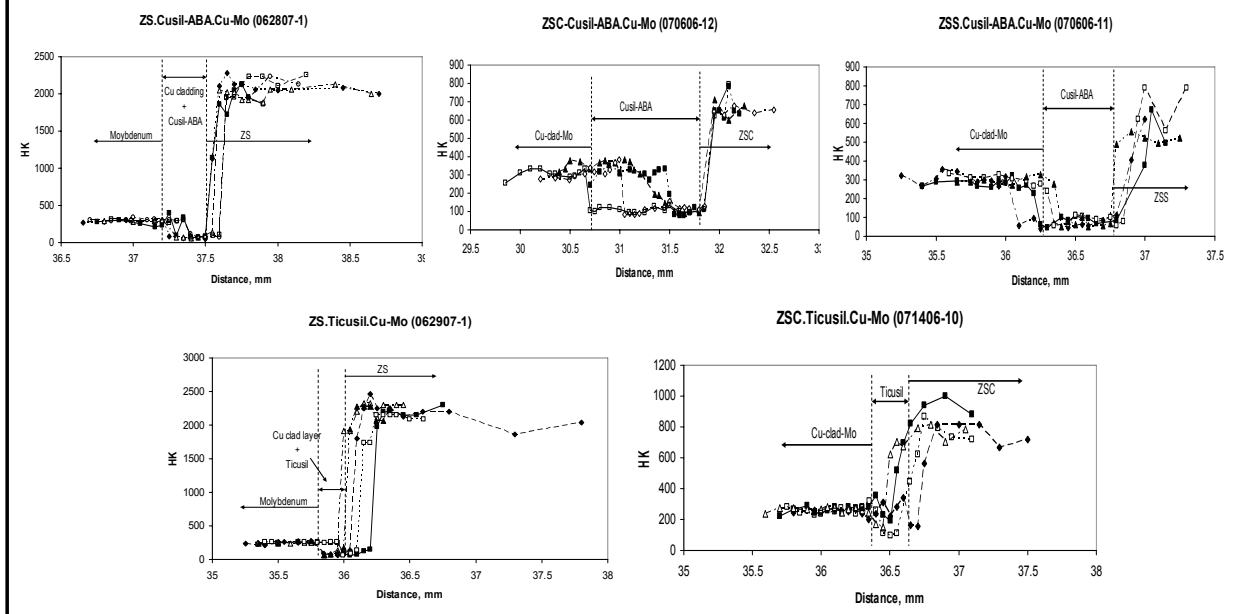

- Hardness of ZSS and ZSC is significantly lower than hardness of ZS.

- Hardness of Ticusil (4.5\% Ti) is slightly higher than hardness of Cusil-ABA (1.75\% Ti).

\section{Knoop Hardness (HK) (Braze: Pd-Co and Pd-Ni)}
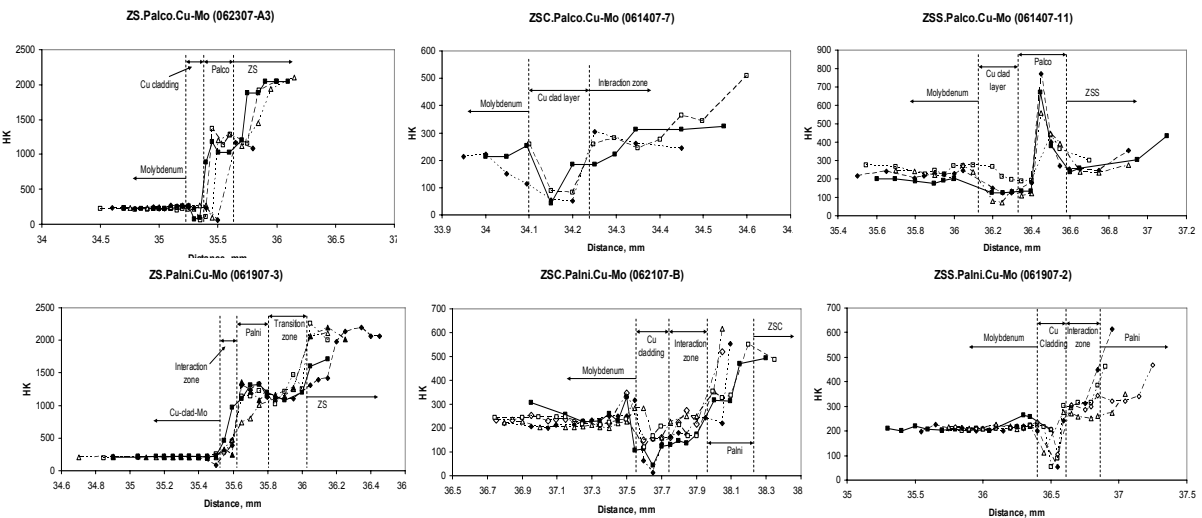

- Palco region in ZSS/Palco joint is less hard than in ZS/Palco joint (porosity and cracks in ZSS; soft $\mathrm{C}$ in ZSC).

- ZS/Palni joints display high hardness within ZS (2200 HK) and Palni (1000-1365 HK).

- For ZSC/Palni and ZSS/Palni joints, hardness of the braze region is low. 
National Aeronautics and Space Administration

\section{Strain Energy in ZS/Cu-clad-Mo Joints vs Clad Layer Thickness}

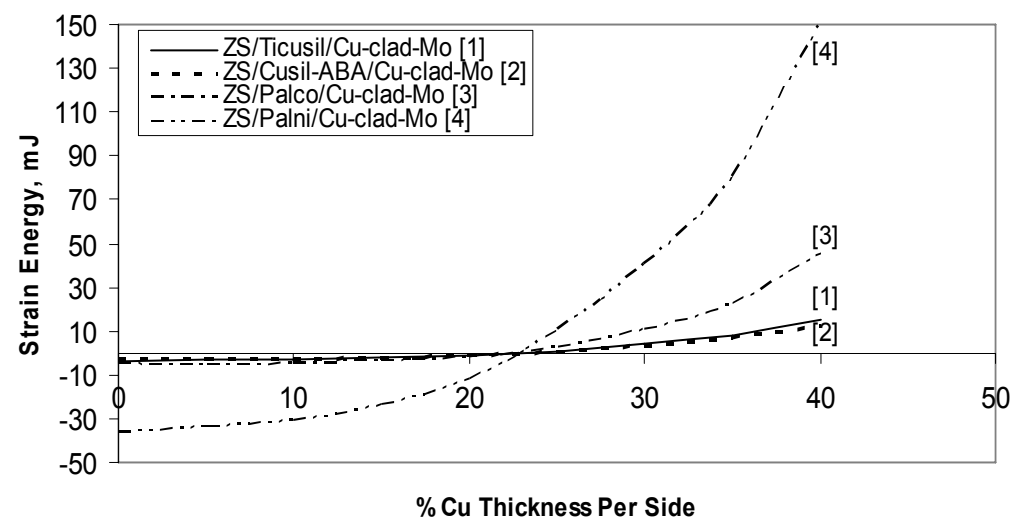

- Strain energy $\left(U_{e c}\right)$ is negative up to $\sim 23 \%$ thickness; above this, $U_{e c}>0$, and increases with increasing thickness $\left(U_{e c}<0\right.$ means increased fracture stress).

- Increase in $U_{e c}$ is largest for Palni and smallest for Cusil-ABA, and inversely related to the yield strength of braze.

- Palni is not recommended for thick cladding (but has highest temperature capability). -There is a small (max. $\sim 15 \%$ ) difference in $U_{e c}$ for Ticusil and Cusil-ABA joints.

\section{Estimation of Thermal Resistance of ZS/Cu-clad-Mo Joints} vs Clad Layer Thickness

Effective thermal resistance (1-D steady-state conduction)

$$
R_{\text {eff }}=\Sigma\left(\Delta x_{i} / K_{i}\right)
$$

( $R_{\text {eff: }}$ effective thermal resistance, $\Delta x_{i}$ : thickness $K_{i}$ : thermal conductivity)

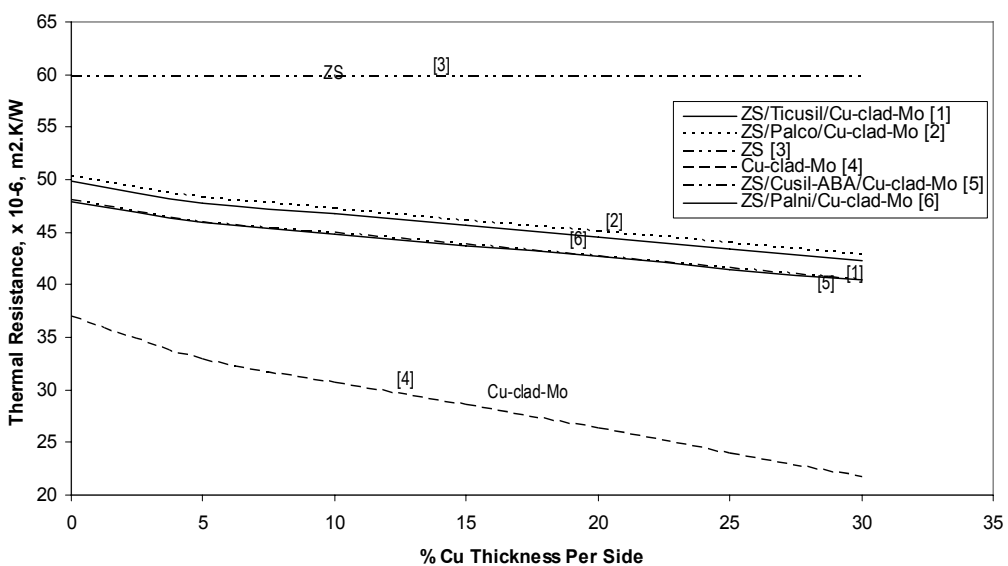


National Aeronautics and Space Administration

Estimation of Thermal Conduction in Brazed Joints

Effective thermal resistance (1-D steady-state conduction) $R_{\text {eff }}=\Sigma\left(\Delta x_{i} / K_{i}\right)$

( $R_{\text {eff: }}$ effective thermal resistance, $\Delta x_{i}$ : thickness $K_{i}$ : thermal conductivity)

- $\mathbf{R}_{\text {eff }}$ decreases with increasing clad layer thickness (e.g., by $\sim 15 \%$ when thickness increases from 0 to $30 \%$ ).

- The values of $R_{\text {eff }}$ for Ticusil and Cusil-ABA joints are nearly identical.

- Because of its miniscule thickness, braze layer makes a negligible contribution to $R_{\text {eff }}$.

- Small changes in $\mathbf{R}_{\text {eff }}$ accompany greater changes in strain energy when clad layer thickness is changed (flexibility in selecting thickness for low CTE mismatch without detriment to thermal conduction).

- Potential benefit to join UHTCC to Cu-clad-Mo to enhance heat dissipation.

National Aeronautics and Space Administration

\section{Concluding Remarks}

- Three hot-pressed $\mathrm{ZrB}_{2}$-based UHTCC were joined to Cu-clad-Mo using AgCuTi brazes $\left(T_{L} \sim 1073-1173 \mathrm{~K}\right)$ and Pd-based brazes $\left(T_{L} \sim 1493-1513 \mathrm{~K}\right)$.

- More extensive interaction occurred in Pd-based braze alloy joints than in AgCuTi-based joints.

- Pd-braze region displayed higher hardness in joints made using ZS than ZSS or ZSC.

- Joints reveal negative strain energy up to $\sim 23 \%$ clad layer thickness. Above $\mathbf{2 3} \%$ thickness, strain energy is positive, and increases with thickness.

- Projected reductions in the thermal resistance highlight the benefits of joining the UHTCC to $\mathrm{Cu}$-clad-Mo. 
National Aeronautics and Space Administration

\section{Acknowledgement}

- Ceramics Branch, NASA Glenn Research Center, Cleveland, for support to R. Asthana. 